and provision of training in surveillance without a solid basis in paediatrics is of limited value. Many general practice trainees undertake a senior house officer post in paediatrics but spend too much time dealing with sick children on the wards and not enough learning about the problems that are common for the general practitioner. There are still insufficient senior house officer posts for all general practice trainees, with no immediate prospect of rectifying this situation. We need a carefully planned paediatric syllabus and training plan for every trainee, designed so that even those who cannot obtain a paediatric post can participate in structured training.

Community secondary care services are now well established, but there are many unsolved problems. Little is known about the functions of the 'district handicap team' and the child protection service, or the reasons for the differences between trusts in the standard and breadth of service provided. There is an impending manpower crisis in children's audiology services. We are still very bad at assessing the benefits of what we do. Information technology promised so much, but at present our computers ingest immense amounts of data at considerable expense, yet give little real information back. The description and analysis of specific learning disability has generated a vast literature; and the service needs of school age children and the place of the school health service have been reviewed recently. ${ }^{8}$ Nevertheless, research into the potential benefits of sophisticated 'educational medicine', the multidisciplinary assessment of children with problems affecting learning, is still virgin territory.

\section{Child health visitors}

'The main justification for the distinction between prevention and treatment has been that they cannot be combined without an unacceptable sacrifice of preventive work ... [but] this distinction is wasteful and confusing to the parents and underestimates the value to the family of having one familiar figure ... [for] health promotion and for illness' (page 108).

Health visitors are currently uncertain of their role. In addition to their traditional work with children and mothers, they are asked to undertake community development projects, specialist work such as tuberculosis contact tracing, and health promotion with adult men, the elderly, or the disabled. The value of their health promoting activities with children is being questioned. Court's analysis was that the health visitor was ideally placed to take on the care of sick children in the community, supported where necessary by a more specialised nurse based within the hospital department. Most of those who fiercely declare their faith in health promotion oppose Court's view. Nevertheless many health visitors would welcome the opportunity to undertake the care of sick children at home, with appropriate support; indeed, this already happens in many informal ways. The sad fact is that we still have little research data to help us decide whether his proposals would (in 1990s jargon) produce more 'health gain' than a purely health promoting model of health visiting.

\section{In conclusion}

The first law of ' $O$ ' level economics tells us that resources are, and always will be, scarce. Donald Court wrote hopefully of a future time when 'the financial crisis would be contained and there would once again be sustained growth in resources and public expenditure' (page 364) but he did not live to see this Utopian state of affairs and I doubt if I shall either.

Rereading Fit for the Future, I reflected that since 1976 the number of consultant paediatricians has increased more than threefold. Should investment in medical care continue to expand at such a rate? Can we make better use of existing resources? Is there a law of diminishing returns as we spend more and more on health care? Would we do better to invest our 'sustained growth in resources', if it ever comes, in housing and education rather than the health care system?

1 Court SDM. Fit for the future. Report of the Committee on Child Health Services. London: HMSO, 1976.

2 British Medical Association. Report of the foint Working Party on Medical Services for Children. London: BMA, 1993. on Medical

3 British Paediatric Association and Specialist Advisory British Paediatric Association and Specialist Advisory Training. Transition guidelines for non-consultant career-grade Training. Transition guidelines for non-consultant career-grade doctors. London: BPA, 1996.

4 British Paediatric Association. Towards a combined child health service. London: BPA, 1991.

5 Anonymous. Surgery needed-a survey of health care. The Economist 6 July 1991: 3-22 (suppl)

6 Department of Health. Child health in the community: a guide to good practice. London: Department of Health, 1996 21-2.

7 Hall DMB. Health for all children: report of the foint Working Party on Child Health Surveillance. Oxford: Oxford University Press, 1989 (1st Ed), 1996 (3rd Ed).

8 Polnay L. The health care needs of school aged children. London: British Paediatric Association, 1996.

\title{
Donald Court: man of vision (1912-94)
}

\author{
A W Craft
}

The 1970 s were a time of consolidation and reflection for paediatrics in the UK. Paediatrics had begun to develop as a separate specialty before the second world war and noteworthy landmarks were the formation of the British Paediatric Association (BPA) in 1928 and the establishment of the first full time professor of child health (James Spence) in England in Infirmary, Newcastle upon Tyne NE1 4LP

Correspondence to: Professor Craft.
1942 in Newcastle upon Tyne. Among the new group of young enthusiastic doctors who came into paediatrics after the war was Donald Court. In the 20 year postwar period the organisation of the care of children underwent a rapid expansion with paediatric units being set up in most major, and many smaller, hospitals. This growth had been largely uncoordi- 
nated and there was clearly a need to take stock and reflect on how far we had come and where to go in the future. Donald Court, one of the leaders of the postwar paediatricians, took a leading role in this and in 1970 he entitled his Charles West Lecture, delivered to the Royal College of Physicians of London, 'Child Health in a Changing Community'. In this he said 'we must continue to strengthen the foundations of paediatrics in the biology of development, extend our studies of the social determinants of health and disease in child and family, especially by the use of well planned local records; seek with psychology and psychiatry for a better understanding of the development of personality in the hope that we may find ways of diminishing maladjustment, excessive anxiety and destructive aggression in our children and parents: treat our patients with increasing skill and consideration and try to as honestly as we can overcome the dichotomy of treatment and prevention: establish these principles in the education of doctors and others professionally involved in the care of children'. 'These ideas were further developed in Paediatrics in the Seventies which he wrote with Tony Jackson when they were chairman and secretary of the Academic Board of the BPA. ${ }^{2}$ It was no surprise therefore when Court was invited by the secretary of state to chair a working party on the future of the child health services, its report being universally known as the Court report. ${ }^{3}$ This report bears his stamp on every page, written in beautiful English, quite unlike the ugly verbiage of many such reports. It was full of compassion, clearly reasoned, and based on careful research. He was greatly saddened and disappointed when it was received with less than enthusiasm by the medical profession and by the politicians who had commissioned it.

In 1978 when Donald Court was being presented with the James Spence medal of the BPA the report was described by Otto Wolff as being a decade or so ahead of its time. ${ }^{4}$ This indeed has proved to be so. Court took quiet pride in seeing most of the reports recommendations being slowly implemented over the next 20 years even though his committee were never given any real credit. It had however clearly achieved its main purpose, to make the country, government, and profession more aware of the needs of children and how they had previously failed them.

There is no doubt therefore that Donald Court was one of the most influential paediatricians of recent times. What then were the sources of greatness, of his depth, his integrity, and his humanity? He was born in Wem, Shropshire, the only child of a headmaster. His mother was the youngest of 17 and it is perhaps understandable why they stopped at Donald. One of his major early achievements was a school certificate examination in gardening of which he was most proud and which was clearly evident in the planning of his gardens in the future. However he was not a practical man and left the execution and manual work to others. It was once said of him 'give him the job and he will finish the tools'. Time for him was better spent in reading than changing a plug. $\mathrm{He}$ initially decided on a career in dentistry but after three years switched to medicine qualifying in Birmingham in 1936. His early work at Great Ormond Street and the Westminster Hospital was followed by the Emergency Medical Service during the war and then to Newcastle as a Nuffield fellow to work with Professor James Spence in his newly formed department. This was a time of great opportunity and he joined a team which was planning the 'Thousand Families' study in which he was particularly active between 1947 and 1954. The Thousand Families work and domiciliary visits led him to the homes of over 3000 families during his first 15 years in Newcastle and these clearly left a great impression on him and eventually led to the ideas first expressed in the Charles West Lecture. ${ }^{1}$ In 1950 on his return from the United States he was appointed reader in child health and succeeded to the chair in 1955 after the untimely death of Spence in 1954.

He always had a view outside of his own specialty and this was fostered when Spence encouraged him to take an interest in speech. This led to him being instrumental in setting up the Department of Speech Therapy in the university and he was also a prime mover behind the new Department of Human Genetics. He had a great ability to work closely with others and his collaborations with Issy Kolvin in child and adolescent psychiatry and Philip Gardner in virology were among the more notable. His work with the virologists was especially important in cementing the links between the largely clinical descriptions of respiratory illness from the past with the rapidly expanding scientific side, enabled by Gardner's pioneering work in rapid viral diagnosis. ${ }^{5}$ Imparting his philosophies to medical students was seen as an important part of his life and he was not only an inspiring and popular teacher but also recognised the stress of medical student training and played a major part in the establishment of a personal tutor system.

His recognition that much of paediatric care takes place outside of hospital was evident in the book which he edited, with the help of 12 local general practitioners entitled The Medical Care of Children. ${ }^{6}$

Donald Court was undoubtedly a man of vision and he was fortunate to follow in the footsteps of Spence who had started the revolution in thinking on the care of children which he successfully carried through.

He was a master wordsmith and his writings are a model of clarity and precision. $\mathrm{He}$ was always able to produce, at the drop at a hat, the apt poetical quotation, often from his favourites Auden and T S Eliot. On research it is perhaps worth quoting Court himself: 'Without continuing enquiry there is no progression. My plea is that we should apply the same critical energy to the study of social as we do to cellular behaviour'.

There is no doubt that Court was greatly helped in his life and work by his strong Quaker philosophy. He came to Quakerism as a student and put the same degree of effort into this as he did to most other things in his life. Much of his thinking about the conflict between religion and science is encapsulated in two articles 
which were published in 1965 and 1970 . These were entitled 'A Scientific Age and a Declining Church" and 'Leading a Double Life'.

$\mathrm{He}$ was a 400 metre runner in his student days and this fleetness of foot and agility was constantly manifest in his future life developing into a well developed political ability. His advice to one young doctor embarking on a potential career in academic paediatrics was that his secret of success was to 'keep both feet firmly planted in mid air!'

Donald Court had a superb capacity to summarise and synthesise and he was in great demand as a chairman. It was no surprise therefore that he was asked to bring together a group of individuals from all walks of life under his chairmanship as the Committee of Enquiry into the Child Health Services. That he brought out the best in people is exemplified by the words of Lady Jean Lovell-Davies. 'Donald Court would have liked to have had children representing their own views on the committee but fortunately for me he had to settle for parents. I was one of three parents chosen to put forward the views of users of the services. I had never previously sat on any sort of committee and, at the first meeting, was totally intimidated by the sight of a huge table with names in front of every seat, just like the ones I had seen on television reports of United Nations meetings. The feelings of foreboding and anxiety expressed themselves in giggles when I heard people using phrases like "through the chair" and other committee speak. I would never have got round to making any contribution at all if Donald had not gone out of his way to ask what each parent representative thought at important moments in the discussion. He gave me the courage to speak and the belief that my views and the views of all children and their families were important'.

There is no doubt that the health of children in the 1990s has been greatly influenced by Donald Court. It would be fitting to close with one of his favourite quotes from T S Eliot.

We shall not cease from exploration And the end of all our exploring Will be to arrive where we started

For to make an end is to make a beginning The end is where we started from.

1 Court SDM. Child health in a changing community. $B M \mathcal{F}$ $1971 ;$ ii: $125-31$

2 Court D, Jackson A. Paediatrics in the seventies. London: Nuffield Provincial Hospital Trust, 1972.

Court SDM. Fit for the future. Report of the Committee on Child Health Services. London: HMSO, 1976.

4 Wolff O. James Spence medallist, 1978, Seymour Donald Mayneord Court. Arch Dis Child 1978;53:609-10.

5 Gardner PS, McQuillan J, Court SDM. Speculation on pathogenesis of death from respiratory syncitial virus infection. BMF 1970;i:327-30.

6 Court SDM, ed. The medical care of children. London: Oxford University Press, 1963.

7 Court SDM. A scientific age and a declining church-what has a friend to say? The Friend September 1965

8 Court SDM. Leading a double life. The Friend September 1970. 